\title{
Immunomodulatory effects of silymarin after subacute exposure to mice: A tiered approach immunotoxicity screening
}

\author{
Gholamreza Karimi ${ }^{1,2}$; Samed Hassanzadeh-Josan²; Bahram Memar ${ }^{3}$; \\ Seyed-Alireza Esmaeili4,5; Bamdad Riahi-Zanjani ${ }^{* *}$
}

${ }^{1}$ Pharmaceutical Research Center, Institute of Pharmaceutical Technology, Mashhad University of Medical Sciences, Mashhad, Iran. ${ }^{2}$ Department of Pharmacodynamics and Toxicology, School of Pharmacy, Mashhad University of Medical Sciences, Mashhad, Iran. ${ }^{3}$ Cancer Research Center, Faculty of Medicine, Mashhad University of Medical Sciences, Mashhad, Iran.

${ }^{4}$ Immunology Research Center, BuAli Research Institute, Faculty of Medicine, Mashhad University of Medical Sciences, Mashhad, Iran.

${ }^{5}$ Student Research Committee, Mashhad University of Medical Sciences, Mashhad, Iran.

${ }^{6}$ Medical Toxicology Research Center, Mashhad University of Medical Sciences, Mashhad, Iran.

\section{Key Words}

Silymarin, Immunomodulatory, Cellular immunity, $\mathrm{Hu}-$ moral immunity

\begin{abstract}
Silymarin is a flavonoid complex extracted from the $\mathrm{Si}$ lybum marianum plant with a wide range of pharmacological and biochemical effects. In the present study, the immunomodulatory effects of silymarin were investigated in BALB/c mice. Silymarin was administered daily by intraperitoneal injection at doses of 50, 100 and 150 $\mathrm{mg} / \mathrm{kg}$ for 14 consecutive days. Following the exposure, host hematological parameters, spleen cellularity and histopathological examination, as well as delayed-type hypersensitivity (DTH) responses, hemagglutination titers (HA), splenocyte cytokine production and lymphocyte proliferation assay were studied in all of the test groups of animals. The results showed that the low dose of silymarin $(50 \mathrm{mg} / \mathrm{kg})$ could stimulate both cellular and humoral immune functions in the treated hosts. In addition, silymarin at $100 \mathrm{mg} / \mathrm{kg}$ appeared to impact on DTH responses and lymphoproliferation. Based on the finding here, it would seem that silymarin has efficient immunostimulant properties. As a recommendation,
\end{abstract}

Received: Dec 23, 2017 Reviewed: May 2, 2018 Accepted: May 6, 2018

(c) This is an Open-Access article distributed under the terms of the Creative Common Attribution Non-Commercial License (http://creativecommons.org/licenses/by-nc/4.0/) which permits unrestricted noncommercial use, distribution, and reproduction in any medium, provided the original work is properly cited.

(@) This paper meets the requirements of KS X ISO 9706, ISO 9706-1994 and ANSI/NISO Z39.48-1992 (Permanence of Paper). the application of silymarin along with acupuncture technique (herbal acupuncture) can be thought as a good plan to modulate and enhance the immune system for the management of several immunodeficiency disorders. However, further studies are required to demonstrate this hypothesis.

\section{Introduction}

The body is protected against foreign agents by the immune system. If the immune response is suppressed, the risks of infection and the development of specific types of cancers are increased. During the last few decades, evaluation of immunosuppression/stimulation of natural compounds has been of keen interest in treatment of special diseases [1-5]. From antiquity, people have sought treatment of their illnesses in nature. The use of natural medicines has been amplified in recent decades due to a low level of side effects and price, in addition to a good efficacy against several human diseases [6]. Silymarin is a flavonoid complex extracted from the Silybum marianum plant (Fig. 1) with a wide range of pharmacological and biochemical effects [7-9]. Silymarin contains some flavonolignans, including silybinin, isosilybinin, silychristin, and silydianin (Fig. 2). In traditional medicine, silymarin has been widely used as a hepatoprotective, anti-in- 
flammatory and anti-carcinogenic agent because of strong antioxidant properties [10-13].

Evidence has indicated that silymarin also may impart some immunomodulatory effects [3, 14- 21]. For example, in an investigation of anti-inflammatory effects of silymarin, this extract attenuated allergic airway inflammation, atopic dermatitis, and allergic rhinitis [19-21]. The immunoprotective effects of silymarin, also have been assessed in UVB-exposed (ultraviolet type B) and sensitized to 2,4-dinitrofluorobenzene (DNFB) mice. Accordingly, they have suggested that silymarin acts to save dendritic cells (DCs) from UV radiation-induced DNA damage and improve UVB-induced DNA damage in DCs [18]. In another investigation, it has been reported that silibinin is a potent inhibitor of phenotypic and functional maturation of lipopolysaccharide (LPS) exposed dendritic cells [17]. This extract was also almost effective to inhibit the production of T helper-1 (TH1) related cytokines [Interleukin-2 (IL-2), Interferon- gamma (IFN- $\gamma$ ), and Tumor necrosis factor-alpha (TNF- $\alpha$ )] by activated-peripheral blood mononuclear cells dose-dependently $[14,15]$. In addition, in another study performed on male BALB/c mice, silymarin inhibited T-lymphocyte function at low doses (10 and $50 \mathrm{mg}$ / $\mathrm{kg}$ ) while stimulates inflammatory processes at, high dose $(250 \mathrm{mg} / \mathrm{kg})$ in a 5-day-regimen. They concluded that silymarin had a broad spectrum of immunomodulatory functions under different conditions [16].

Because the aforementioned studies only investigated the effects of silymarin on just a few aspects of the immune system, a study appeared necessary, one that is based on the tiered- approach to immunomodulatory screening [22]. Such studies are also needed in that, as noted above, some data were conflicting, thus limiting the potential wider use of silymarin as a therapeutic immunomodulant. Thus, due to this overall lack of information about the immunotoxic effects of silymarin, the present study was carried out to investigate such effects following a set of subacute exposures in mice.

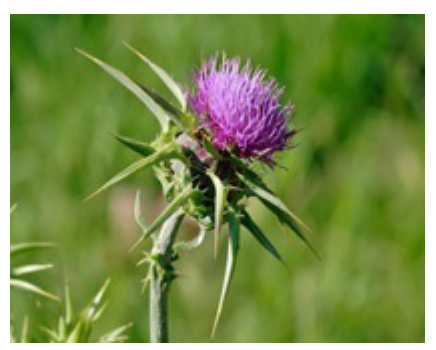

Figure 1 Silybum marianum
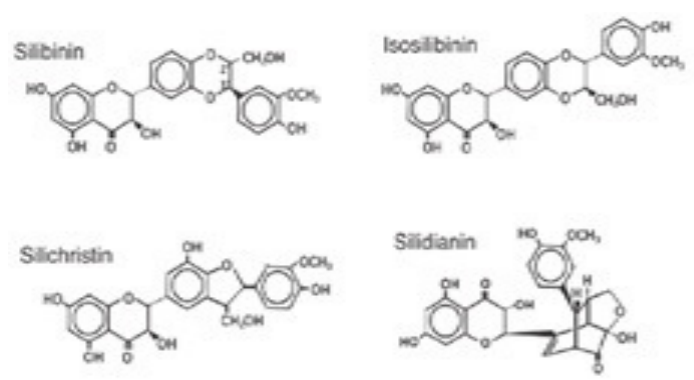

Figure 2 The major components of silymarin

\section{Materials and Methods}

\section{Animals}

BALB/c inbred mice (female, 19-21 g, 6-8 weeks old) were purchased from the Pharmacy School of Mashhad, Iran and kept in large polystyrene cages and provided free access to rodent chow and water with an ambient temperature of $20-25^{\circ} \mathrm{C}$ with a $12 \mathrm{~h}$ light/dark lighting cycle. Animals were allowed to acclimate for at least one week prior to use. All protocols used in this study were approved by the Ethic Council of Mashhad University of Medical Sciences, Mashhad, Iran.

\section{Chemicals}

Phytohemagglutinin-A (PHA), lipopolysaccharide (LPS), cyclophosphamide (CYP) and silymarin were obtained from Sigma (UK) Company while fetal bovine serum (FBS) and RPMI- 1640 medium were taken from Gibco (UK). Sheep red blood cells (SRBCs) were obtained from Razi Institute (Mashhad, Iran). IFN $\gamma$ and IL4 ELISA kits were obtained from eBioscience Company.

\section{Doses and exposure schedules}

Dedicated sets of female BALB/c mice were used for each experiment. Five subsets of female BALB/c mice ( $n=6$ /group) were administered by three doses of silymarin, normal saline as negative and cyclophosphamide as positive controls. Mice in silymarin groups were injected intraperitoneally daily with a silymarin solutions (prepared in normal saline) to receive 50,100 and $150 \mathrm{mg} / \mathrm{kg}$ of silymarin for 14 consecutive days. Mice in the negative and positive control groups received only normal saline and cyclophosphamide ( $20 \mathrm{mg} / \mathrm{kg} /$ day $)$ injections for 14 days, respectively. All injection volumes were $100 \mu \mathrm{l}$.

\section{Determination of the hematological parameters}

Each mouse underwent blood sampling from the retro-orbital plexus (before being sacrificed) by capillary tubes. Two hundred microliters of blood from each mouse was dispensed in a sterile anti-coagulated Ethylene diamine tetra acetic acid dipotassium salt (K2-EDTA) tube to allow hematological indexes determinations. Furthermore, a smear of peripheral blood was also provided, stained with Giemsa, and then observed under a light microscope for differential count of leukocytes [23].

\section{Histopathological examination}

On day 15, different groups of animals were euthanized by cervical dislocation and spleen of each animal was then removed and stabilized in a solution of $10 \%$ formalin. Afterwards, the process of mounting of tissues was performed followed by staining of $5-\mu \mathrm{m}$ thick sections of these tissues with Hematoxylin \& Eosin (H\&E). Furthermore, the femurs of mice were isolated and bone marrow smears provided and stained with H\&E. Histopathological alterations of spleen and bone marrow in different groups 
of mice were then assessed through light microscopy [24].

\section{Preparation of single-cell suspension}

Each spleen removed was put into a small, clear and round dish containing $10 \mathrm{ml}$ RPMI-1640 media supplemented with $100 \mathrm{U} / \mathrm{ml}$ penicillin, $100 \mu \mathrm{g} / \mathrm{ml}$ streptomycin, $10 \%$ fetal bovine serum (FBS), and $2 \mathrm{mM}$ glutamine. The spleen was disrupted between two frosted slides and the tissue dispersion formed was filtered via a nylon mesh with pore size of $40 \mu \mathrm{m}$ and collected in a Falcon $50 \mathrm{ml}$ centrifuge tube and then centrifuged at $1200 \mathrm{rpm}$ at 4 for $10 \mathrm{~min}$. The

supernatant was decanted and the pellet re-mixed in $3 \mathrm{ml}$ of RBC lysis buffer $(0.83 \% \mathrm{NH} 4 \mathrm{Cl}$ in $100 \mathrm{mM}$ Tris buffer, $\mathrm{pH}$ 7.4) and incubated at room temperature for $3 \mathrm{~min}$. Following three times washing of the cells with the media, the final pellet was suspended into $1 \mathrm{ml}$ of the media containing $10 \%$ FBS. Spleen cell count was measured using the Neubauer chamber. Viability of cells was carried out using the trypan blue exclusion method [23].

\section{Hemagglutination assay}

On Day 10, the mice in each regimen were immunized by i.p. injection by $5 \times 108$ SRBCs in PBS. Injection of silymarin was resumed until day 14 . At the termination of experiment, after preparing sera from peripheral blood samples, aliquots $(50 \mu \mathrm{l})$ of two-fold dilutions of the sera (in PBS) were combined with $50 \mu \mathrm{l}$ of a $2 \%$ [v/v] SRBCs suspension in a glass tubes. The tubes were kept at $37^{\circ} \mathrm{C}$ for 2 hours and then assessed for hemagglutination. The highest dilution giving hemagglutination was taken as the antibody titer [23].

\section{Lymphocyte proliferation test}

This experiment was performed as previously described [23]. Briefly, the $100 \mu \mathrm{l}$ aliquots of the splenocytes isolated above at $2 \times 106$ cells $/ \mathrm{ml}$ were dispensed into wells of a 96-well microtiter plate. Afterwards, complete media or Phytohemagglutinin-A (PHA at a final level of $5 \mu \mathrm{g} / \mathrm{ml}$ ) or lipopolysaccharide (LPS at a final concentration of $1 \mu \mathrm{g}$ / $\mathrm{ml}$ ) was added to triplicate designated wells. The plates were then incubated for $48 \mathrm{~h}$ at $37^{\circ} \mathrm{C}$ in a CO2 (5\%) humid incubator and then cell proliferation was measured by an MTT [3-(4,5-diamethyl-2-thiazolyl)2,5-diphenyl-2H- tetrazolium] colorimetric assay. For this, $15 \mu \mathrm{l}$ MTT solution with a concentration of $5 \mathrm{mg} / \mathrm{ml}$ was added to each well at $37^{\circ} \mathrm{C}$ in $\mathrm{CO} 2$ humid incubator for a further 4 hours. The blue formazan formed was then dissolved by addition of $100 \mu \mathrm{l}$ dimethylsulfoxideand (DMSO) and the absorbance of the wells was measured at $570 \mathrm{~nm}$ by using Stat-FaxTM Elisa Reader. Proliferation index (PI) was calculated as follows:

$\mathrm{PI}=$ Absorbance of stimulated cells/Absorbance of unstimulated cells.

\section{Delayed-type hypersensitivity response (DTH)}

Delayed-type hypersensitivity response (DTH) was performed for experimental and control groups of mice using the method of Riahi et al [23]. On Day 9 of treatment, mice in each regimen were primed i.p. with $100 \mu \mathrm{l}$ of a SRBCs solution containing 109 cells. Five days later, all mice were re- challenged with a booster dose of 108/50 $\mu \mathrm{l} \mathrm{SRBCs}$ in the left hind footpad. As trauma control for elimination of non-specific swelling, the right hind footpad was injected with the same volume of PBS. Mean percentage increase in footpad thickness was calculated $24 \mathrm{~h}$ after the SRBCs challenge as following formula.

\section{(Left footpad challenged with SRBC - Right footpad) $\times 100$ Right footpad}

\section{Cytokine production}

For this experiment, the supernatants harvested, subsequent to $48 \mathrm{~h}$ of splenocyte cultivation in the presence of PHA, were kept at $\_70^{\circ} \mathrm{C}$ until analysis. The levels of cytokines produced (IFN $\gamma$ and IL-4) by splenocytes in supernatants were determined using commercially available ELISA kits according to the manufacturer's protocol [23].

\section{Statistical analysis}

Data were statistically analyzed by Student's t-test to assess significant changes in the data of different groups. $P$ values less than 0.05 were supposed significant. The values are expressed as means \pm SEM.

Table 1 Effect of subacute exposure to silymarin i.p. for 14 days on mice hematological parameters as well as spleen cellularity

\begin{tabular}{|c|c|c|c|c|c|}
\hline Parameter & $\begin{array}{l}\text { Silymarin } \\
50 \mathrm{mg} / \mathrm{kg}\end{array}$ & $\begin{array}{l}\text { Silymarin } \\
100 \mathrm{mg} / \mathrm{kg}\end{array}$ & $\begin{array}{l}\text { Silymarin } \\
150 \mathrm{mg} / \mathrm{kg}\end{array}$ & Normal Saline & $\begin{array}{c}\text { Cyclophosphamide } \\
20 \mathrm{mg} / \mathrm{kg}\end{array}$ \\
\hline WBC $\left(\right.$ count $\left.\times 10^{3} / \mu 1\right)$ & $14.1 \pm 1.44$ & $13.4=1.89$ & $14.8 \pm 2.48$ & $12.5 \pm 2.30$ & $4.4 \pm 2.08^{*}$ \\
\hline $\mathrm{RBC}\left(\right.$ count $\left.\times 10^{6} / \mu \mathrm{l}\right)$ & $8.3=0.29$ & $9.6 \pm 0.10$ & $9.1 \pm 0.29$ & $9.3 \pm 0.29$ & $8.7 \pm 0.42$ \\
\hline Hct $(\%)$ & $41.4 \pm 2.10$ & $49.7 \pm 0.71$ & $47.4 \pm 2.17$ & $46.5 \pm 2.56$ & $47.0 \pm 2.33$ \\
\hline $\mathrm{Hb}(\mathrm{g} / \mathrm{dl})$ & $13.23 \pm 0.3772$ & $15.30 \pm 0.1975$ & $14.20 \pm 0.5845$ & $14.02 \pm 0.7358$ & $14.18 \pm 0.4191$ \\
\hline Plt $\left(\right.$ count $\left.\times 10^{3} / \mu \mathrm{l}\right)$ & $963 \pm 127$ & $1292 \pm 74$ & $1222 \pm 229$ & $1026 \pm 105$ & $946 \pm 267$ \\
\hline $\mathrm{MCH}(\mathrm{pg})$ & $15.9 \pm 0.40$ & $15.9 \pm 0.15$ & $15.4 \pm 0.27$ & $14.8 \pm 0.42$ & $16.2 \pm 0.44$ \\
\hline $\mathrm{MCHC}(\mathrm{g} / \mathrm{dl})$ & $32.05 \pm 0.8884$ & $31.02 \pm 0.2059$ & $29.95 \pm 0.2872$ & $30.10 \pm 0.1844$ & $30.20 \pm 0.6621$ \\
\hline $\mathrm{MCV}(\mathrm{fl})$ & $49.6 \pm 1.19$ & $51.3 \pm 0.48$ & $51.6 \pm 0.91$ & $49.3 \pm 1.43$ & $53.7 \pm 0.69$ \\
\hline Neutrophil $\left(\right.$ count $\left.\times 10^{3} / \mu \mathrm{l}\right)$ & $5.5 \pm 1.03 *$ & $4.2 \pm 0.81$ & $3.9 \pm 0.52$ & $2.4 \pm 0.84$ & $2.2 \pm 1.32$ \\
\hline Lymphocyte (count $\left.\times 10^{3} / \mu \mathrm{l}\right)$ & $8.0 \pm 0.85$ & $8.9 \pm 1.18$ & $10.5 \pm 1.94$ & $9.7 \pm 1.70$ & $3.3 \pm 1.50^{*}$ \\
\hline $\operatorname{MXD}\left(\right.$ count $\left.\times 10^{3} / \mu 1\right)$ & $0.57 \pm 0.153$ & $0.31=0.053$ & $0.37 \pm 0.088$ & $0.400 \pm 0.142$ & $0.17 \pm 0.033$ \\
\hline Spleen cell content $\left(\times 10^{6}\right)$ & $33.6 \pm 0.97 *$ & $31.6 \pm 3.48$ & $30.0 \pm 3.46$ & $25.0 \pm 3.32$ & $1.73 \pm 0.62^{* * *}$ \\
\hline $\begin{array}{l}\text { WBC: White blood } \\
\text { corpuscular hemogle } \\
\text { MXD: The sum of } n \\
\text { compared to the neg } \\
\text { group. }\end{array}$ & $\begin{array}{l}\text { es and eosino } \\
\text { introl group. }\end{array}$ & 0.001 indicates & $\begin{array}{l}n \pm \text { SEM. } * p< \\
\text { ificant changes }\end{array}$ & $\begin{array}{l}\text {; Plt: Platelet; } \\
\text { : Mean corpusc } \\
\text { indicates signif } \\
\text { npared to the ne }\end{array}$ & $\begin{array}{l}\text { ICH: Mean } \\
\text { lar volume; } \\
\text { ant changes } \\
\text { tive control }\end{array}$ \\
\hline
\end{tabular}




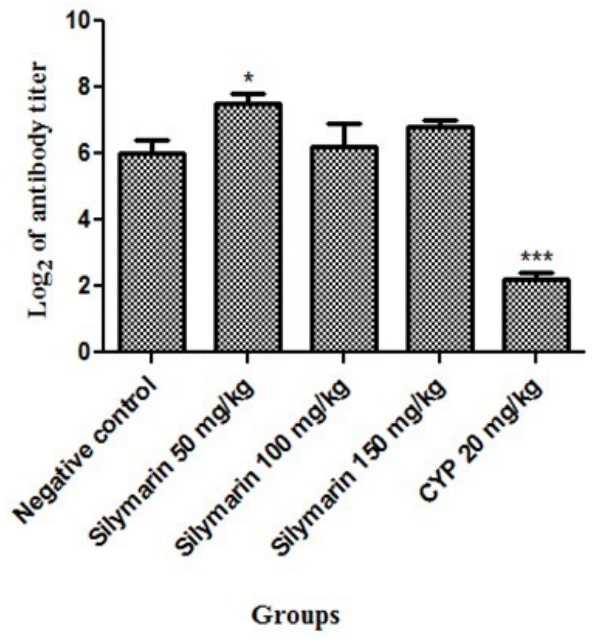

Figure 3 Effect of subacute exposure to silymarin i.p. for 14 days on mice antibody response. Data shown as mean \pm SEM. ${ }^{*} p<0.05$ indicates significant changes compared to the negative control group. ${ }^{* * *} \mathrm{p}<0.001$ indicates significant changes compared to the negative control group.

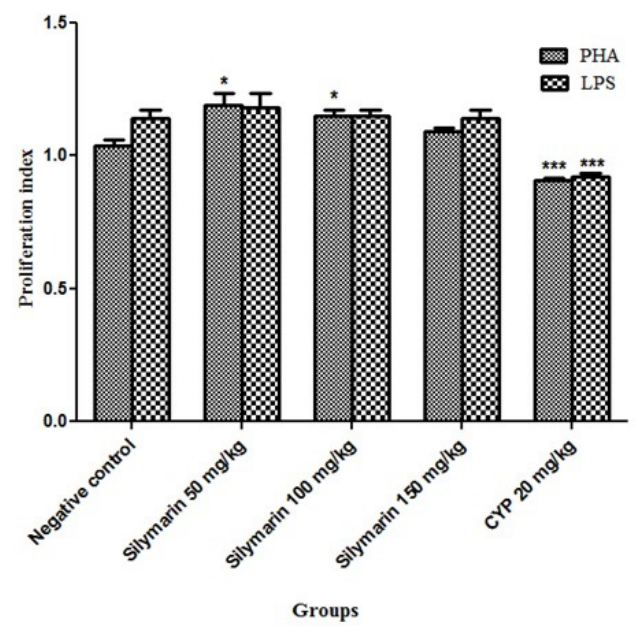

Figure 5 Effect of subacute exposure to silymarin i.p. for 14 days on mice lymphoproliferation response to PHA and LPS. Data shown as mean \pm SEM. ${ }^{*} \mathrm{p}<0.05$ indicates significant changes compared to the negative control group. ${ }^{* * *} \mathrm{p}<0.001$ indicates significant changes compared to the negative control group.

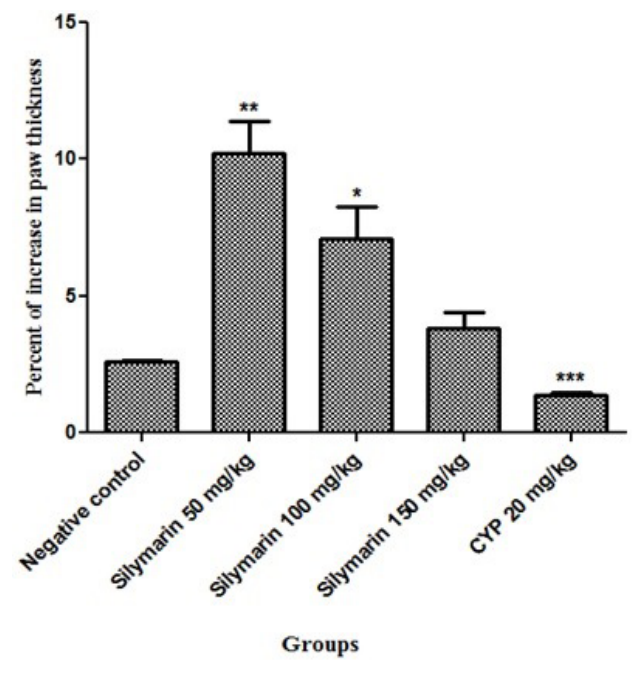

Figure 4 Effect of subacute exposure to silymarin i.p. for 14 days on mice DTH response. Data shown as mean \pm SEM. ${ }^{*} \mathrm{p}<0.05$ indicates significant changes compared to the negative control group. ${ }^{* *} \mathrm{p}<0.01$ indicates significant changes compared to the negative control group. ${ }^{* * *} \mathrm{p}<0.001$ indicates significant changes compared to the negative control group.

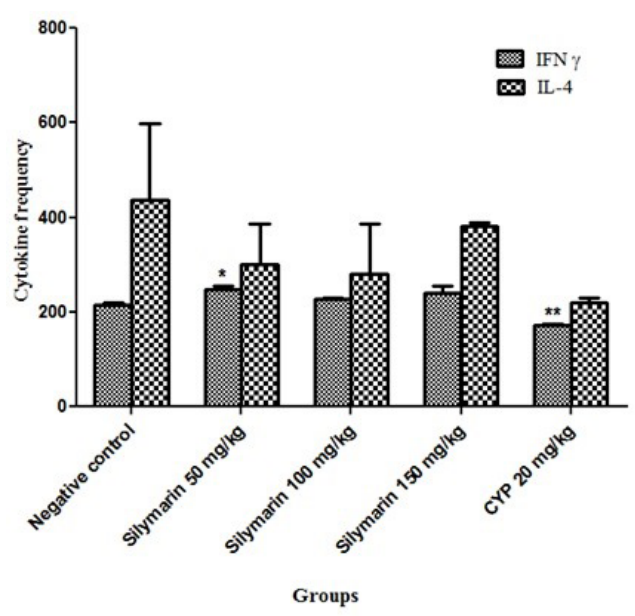

Figure 6 Effect of subacute exposure to silymarin i.p. for 14 days on cytokine produced $(\mathrm{pg} / \mathrm{ml}$ ) by isolated mice splenocytes. Data shown as mean \pm SEM. ${ }^{*} \mathrm{p}<0.05$ indicates significant changes compared to the negative control group. ${ }^{* *} \mathrm{p}<0.01$ indicates significant changes compared to the negative control group. 


\section{Results}

\section{Hematological parameters and spleen cellularity}

None of the doses of silymarin caused mortality in the present study. The hematological findings and spleen cellularity in different groups of mice are shown in Table 1. Measures of the parameters in silymarin treated groups (except the neutrophil count) did not show any significant differences as compared to negative control. However, a significant increase in the neutrophil count of $50 \mathrm{mg} / \mathrm{kg}$ silymarin group was observed $(\mathrm{p}<0.05)$. In addition, spleen cellularity changed significantly at dose of $50 \mathrm{mg} / \mathrm{kg} / \mathrm{day}(\mathrm{p}<0.05)$. Cyclophosphamide (CYP) caused significant reductions in leukocyte and lymphocyte levels $(\mathrm{p}<0.001)$ and also affected the levels of spleen cells in these hosts $(\mathrm{p}<0.001)$.

\section{Histopathological examination}

Spleen

Spleen was investigated in terms of any atrophy or hyperplasia in white pulp, white pulp: red pulp ratio, as well as the presence of any abnormality including necrosis, apoptosis, clumps, and debris in the white and red pulp regions. Also, any splenic trabecular abnormality was evaluated. The light microscopic evaluation of spleen tissue showed that silymarin at all doses did not have any significant side effect on spleen.

\section{Bone marrow}

Each bone marrow isolated was analyzed in terms of some important parameters such as maturation/presence of hematopoietic cell subtypes, cellularity, in addition to amount of the erythroid lineage relative to myeloid lineage. The observational analysis revealed that there was no significant pathologic change among the tissue samples obtained from the different silymarin groups as compared to negative controls.

\section{Hemagglutination (HA) titer assay}

Measures of serum anti-SRBC titer of $50 \mathrm{mg} / \mathrm{kg}$ silymarin group showed a significant increase as compared to negative control group whereas the amount of antibody against SRBCs in other groups of silymarin had no significant changes relative to negative controls $(\mathrm{p}<0.05)$. Cyclophosphamide significantly $(\mathrm{p}<0.001)$ decreased generation of anti-SRBC antibody (Figure 3).

\section{Delayed-Type Hypersensitivity (DTH) response}

With regard to evaluation of DTH response, there were significant suppression in $24 \mathrm{~h}-\mathrm{DTH}$ response of silymarin treated groups at doses of $50 \mathrm{mg} / \mathrm{kg}(\mathrm{p}<0.01)$ and $100 \mathrm{mg} /$ $\mathrm{kg}(\mathrm{p}<0.05)$ when compared with negative controls (Figure 4). Cyclophosphamide group showed a significant decrease in DTH response $(\mathrm{P}<0.001)$.

Proliferation responses to PHA or LPS
The results clearly demonstrated effects on the inducible proliferative responses of lymphocytes from mice treated with silymarin at doses of 50 and $100 \mathrm{mg} / \mathrm{kg}$ in comparison with values seen with cells from the control hosts $(\mathrm{p}<$ 0.05) (Figure 5). In contrast, PI (subsequent to LPS stimulation) values for the cells from mice treated with these three regimens were not found to have significant differences relative to negative control host (LPS-stimulated) PI levels. In addition, the positive control significantly decreased the proliferative response subsequent to PHA and LPS stimulation $(\mathrm{p}<0.001)$.

\section{Cytokine production}

Host treatment with silymarin at $50 \mathrm{mg} / \mathrm{kg} /$ day significantly increased the ex vivo IFN $\gamma$ production of their splenocytes in response to PHA $(\mathrm{p}<0.05)$ relative to that by negative control mice splenocytes (Figure 6). On the other hand, IL-4 production by these same cells was not significantly affected by any doses of silymarin. Moreover, the positive control significantly reduced the production of IFN $\gamma(\mathrm{p}<0.01)$, while IL-4 generated by splenocytes did not show any changes in this group as compared to negative controls.

\section{Discussion}

Since the silymarin, as a traditional medicine or dietary supplement, has been believed that has a low toxicity and because it is critical to have a healthy immune system, this study was considered to evaluate potential immunomodulatory effects of silymarin after a subacute exposure. In this study, the potential immunomodulatory effects of silymarin in mice were explored. In the present study, a dose of $50 \mathrm{mg}$ silymarin $/ \mathrm{kg}$ caused significant stimulation in the immune endpoints examined. Specifically, silymarin at a dose of $50 \mathrm{mg} / \mathrm{kg} /$ day significantly increased the peripheral neutrophil and the spleen cell counts. In addition, a significant increase in PHA-induced splenocyte proliferation response (PI values) from the $50 \mathrm{mg} / \mathrm{kg}$ silymarin-treated mice suggested a stimulatory effect on the activation/ proliferation of T-cells; these effects, in turn, appeared to manifest as enhanced DTH and HA response. Of course, silymarin at all doses did not show any changes in LPS-induced splenocyte proliferation response, suggesting that an increase in serum antibody against SRBCs (a T-dependent antigen) at a dose of $50 \mathrm{mg} / \mathrm{kg}$ may be secondary to $\mathrm{T}$ cells stimulation. On the other hand, a significant increase in the absolute numbers of spleen cells in the $50 \mathrm{mg}$ silymarin/kg mice suggested that there was a stimulatory effect on the production of lymphocytes in primary lymphatic organs and/or on the deposition of blood lymphocytes in spleen. Moreover, the data here showed that silymarin at a level of $100 \mathrm{mg} / \mathrm{kg}$ caused stimulatory effects on some of the assessed endpoints, such as DTH responses after $24 \mathrm{~h}$ and lymphoproliferation assay in the presence of PHA. However, silymarin at a dose of $150 \mathrm{mg} / \mathrm{kg}$ was unable to induce any significant changes in immunological parameters.

As noted earlier, some of the immunomodulatory properties of silymarin observed here might be due to a direct effect on the activation/differentiation of lymphocytes. 
T-cells arrange the acquired immune response and are essential for guarding and immunological memory. During the time naive T-cells are stimulated by foreign antigen, they experience an activation program in which they proliferate and then differentiate into effector subtypes [25].

There are studies showing that reactive oxygen species (ROS) can operate as signaling mediators in the above-mentioned processes [26-28]. Low levels of ROS are vital in inducing transcription of NF- $\mathrm{KB}$ and expression of genes for several essential cytokines and receptors needed for the proliferation of T-cell [29].

On the other hand, because unsaturated fatty acid side chains of phospholipids in cell membranes are vulnerable to free radicals attack, this effect could lead to reduced immune cell membrane fluidity. [30]. In normal circumstances the interaction of lymphocytes with antigens and other cell subsets needs the cell membrane integrity. Lower levels of intracellular antioxidants such as GSH in T-cells make them more susceptible to lipid peroxidation [31, 32]. Therefore in our study, silymarin at lower doses (50 and $100 \mathrm{mg} / \mathrm{kg}$ ) may have acted as a potent antioxidant to remove any additional ROS that could partake in the disruption of T-cells membrane fluidity, ultimately resulting in overall immunostimulation. On the other hand, silymarin at dose of $150 \mathrm{mg} / \mathrm{kg}$ did not produce any significant change in non-functional/functional parameters of mice immune system. This may be related to the importance of the intracellular redox (reduction- oxidation) state in terms of maintaining correct function of immune cells. Indeed, the balance between oxidizing and reducing agents within immune cells controls their redox state. Temporary controlled changes of redox state such as increased formation of ROS is necessary for induction of various biological processes like activation and proliferation of immune cells $[33,34]$. As a result, the absence of immunomodulatory effect of silymarin at high dose $(150 \mathrm{mg} / \mathrm{kg})$ may be due to scavenging both additional ROS and needed ROS for activation/proliferation of lymphocytes.

In addition, in our study, a significant increase in IFN $\gamma$ and an insignificant decrease in IL-4 formation in cultures of spleen cells was observed with cells from mice treated with the lower dose $(50 \mathrm{mg} / \mathrm{kg}$ ) of silymarin, suggesting a shift in the host to a more T-helper TH-1 cell based response. While the expansion of IFN $\gamma$-producing TH1 cells would promote cell-mediated immunity, the expansion of IL-4-producing TH2 cells would increase generation of regulatory T- cells and, thus, weaken immune system reactions [35]. This shift may be an important factor in the overall observed immunostimulatory effects of silymarin; further study is underway to confirm this.

\section{Conclusion}

In conclusion, the current study showed that silymarin at low doses (i.e. 50 and $100 \mathrm{mg} / \mathrm{kg} /$ day for 14 days) imparted a stimulatory effect on mice immune system. At higher dose (i.e. $150 \mathrm{mg} / \mathrm{kg} /$ day), however, silymarin was unable to affect the immunological parameters. Further studies are needed to better determine the immunomodulatory properties of this natural product. Mechanistic studies can clarify precisely how this material is acting to impart the immunomodulatory effects demonstrated here. Par- ticularly, studies should be performed to measure levels of ROS formed by mouse splenocytes after silymarin treatment and alterations in the activation of pathways in which ROS operate as a signal transduction intermediates in these cells.

\section{Acknowledgements}

The authors are thankful to the Vice Chancellor of Research, Mashhad University of Medical Sciences for financial support.

\section{Conflict of interest}

The authors declare that there are no conflicts of interest. 


\section{References}

1. Farsam V, Hassan ZM, Zavaran-Hosseini A, Noori S, Mahdavi M, Ranjbar M. Antitumor and immunomodulatory properties of artemether and its ability to reduce CD4+ CD25+ FoxP3+ T reg cells in vivo. Int Immunopharmacol. 2011;11(11):1802-8.

2. Riahi-Zanjani B, Balali-Mood M, Mohammadi E, Badie-Bostan H, Memar B, Karimi G. Safranal as a safe compound to mice immune system. Avicenna J Phytomed. 2015;5(5):441.

3. Shirani K, Hassani FV, Razavi-Azarkhiavi K, Heidari S, Zanjani BR, Karimi G. Phytotrapy of cyclophosphamide-induced immunosuppression. Environ Toxicol Pharmacol. 2015;39(3):1262-75.

4. Noori S, Taghikhani M, Hassan ZM, Allameha A, Mostafaei A. Tehranolide molecule modulates the immune response, reduce regulatory $\mathrm{T}$ cell and inhibits tumor growth in vivo. Molecul Immunol. 2010;47(7):1579-84.

5. Rahnama M, Mahmoudi M, Zamani Taghizadeh Rabe S, Balali-Mood M, Karimi G, Tabasi N, et al. Evaluation of anti-cancer and immunomodulatory effects of carnosol in a Balb/c WEHI-164 fibrosarcoma model. J Immunotoxicol. 2015;12(3):231-8.

6. Hasani-Ranjbar S, Larijani B, Abdollahi M. A systematic review of the potential herbal sources of future drugs effective in oxidant-related diseases. Inflamma Allergy Drug Targets. 2009;8(1):2-10.

7. Elyasi S, Shojaee FSR, Allahyari A, Karimi G. Topical Silymarin Administration for Prevention of CapecitabineXInduced Hand-Foot Syndrome: A Randomized, Double冈Blinded, Placebo-Controlled Clinical Trial. Phytother Res. 2017;31(9):1323-9.

8. Elyasi S, Hosseini S, Niazi Moghadam MR, Aledavood SA, Karimi G. Effect of Oral Silymarin Administration on Prevention of Radiotherapy Induced Mucositis: A Randomized, Double冈Blinded, Placebo®Controlled Clinical Trial. Phytother Res. 2016;30(11):1879-85.

9. Karimi G, Vahabzadeh M, Lari P, Rashedinia M, Moshiri M. "Silymarin", a promising pharmacological agent for treatment of diseases. Iran J Basic Med Sci. 2011(4);14:308.

10. Agarwal R, Agarwal C, Ichikawa H, Singh RP, Aggarwal BB. Anticancer potential of silymarin: from bench to bed side. Anticancer Res. 2006;26(6B):4457-98.

11. Vargas-Mendoza N, Madrigal-SantillánE, Morales-González Á, Esquivel-Soto J, Esquivel- Chirino C, y González-Rubio MG-L, et al. Hepatoprotective effect of silymarin. World J Hepatol. 2014;6(3):144.

12. Razavi BM, Karimi G. Protective effect of silymarin against chemical-induced cardiotoxicity. Iran J Basic Med Sci. 2016;19(9):916.

13. Darvishi Khezri H, Salehifar E, Kosaryan M, Aliasgharian A, Jalali H, Hadian Amree A. Potential effects of silymarin and its flavonolignan components in patients with \-Thalassemia major: a comprehensive review in 2015. Adv Pharmacol Sci. 2016;2016.

14. Gharagozloo M, Velardi E, Bruscoli S, Agostini M, Di Sante M, Donato V, et al. Silymarin suppress CD4+ T cell activation and proliferation: Effects on NF- $\kappa \mathrm{B}$ activity and IL-2 production. Pharmacol Res. 2010;61(5):405-9.

15. Morishima C, Shuhart MC, Wang CC, Paschal DM, Apodaca MC, Liu Y, et al. Silymarin inhibits in vitro T-cell proliferation and cytokine production in hepatitis $\mathrm{C}$ virus infection. Gastroenterol. 2010;138(2):671-81. e2.

16. Johnson VJ, He Q, Osuchowski MF, Sharma RP. Physiological Responses of a Natural Antioxidant Flavonoid Mixture, Silymarin, in BALB/c Mice. Planta Med 2003;69(01):44-9.

17. Lee JS, Kim SG, Kim HK, Lee TH, Jeong YI, Lee CM, et al. Silibinin polarizes Th1/Th2 immune responses through the inhibition of immunostimulatory function of dendritic cells. J Cell Physiol. 2007;210(2):385-97.

18. Vaid M, Prasad R, Singh T, Elmets CA, Xu H, Katiyar SK. Silymarin inhibits ultraviolet radiation-induced immune suppression through DNA repair-dependent activation of dendritic cells and stimulation of effector T cells. Biochem Pharmacol. 2013;85(8):1066-76.

19. Mady FM, Essa H, El-Ammawi T, Abdelkader H, Hussein AK. Formulation and clinical evaluation of silymarin pluronic-lecithin organogels for treatment of atopic dermatitis. Drug Des Devel Ther. 2016;10:1101.

20. Choi YH, Jin GY, Guo HS, Piao HM, chang Li L, Li GZ, et al. Silibinin attenuates allergic airway inflammation in mice. Biochem Biophys Res Commun. 2012;427(3):450-5.

21. Bakhshaee M, Jabbari F, Hoseini S, Farid R, Sadeghian $\mathrm{MH}$, Rajati M, et al. Effect of silymarin in the treatment of allergic rhinitis. Otolaryngol Head Neck Surg. 2011;145(6):904-9.

22. Luster MI, Dean JH, Germolec DR. Consensus workshop on methods to evaluate developmental immunotoxicity. Environ health perspect. 2003;111(4):579.

23. Riahi B, Rafatpanah $\mathrm{H}$, Mahmoudi M, Memar B, Brook A, Tabasi N, et al. Immunotoxicity of paraquat after subacute exposure to mice. Food Chem Toxicol. 2010;48(6):1627-31.

24. Neishabouri EZ, Hassan Z, Azizi E, Ostad S. Evaluation of immunotoxicity induced by diazinon in $\mathrm{C} 57 \mathrm{bl} / 6$ mice. Toxicology. 2004;196(3):173-9.

25. Sena LA, Li S, Jairaman A, Prakriya M, Ezponda T, Hildeman DA, et al. Mitochondria are required for antigen-specific $\mathrm{T}$ cell activation through reactive oxygen species signaling. Immunity. 2013;38(2):225-36.

26. Schieke SM, McCoy Jr JP, Finkel T. Coordination of mitochondrial bioenergetics with G1 phase cell cycle progression. Cell Cycle. 2008;7(12):1782-7.

27. Byun HO, Kim HY, Lim JJ, Seo YH, Yoon G. Mitochondrial dysfunction by complex II inhibition delays overall cell cycle progression via reactive oxygen species production. J Cell Biochem. 2008;104(5):1747-59.

28. Keramati MR, Balali-Mood M, Mousavi SR, Sadeghi M, Riahi-Zanjani B. Biochemical and hematological findings of Khorasan veterans 23 years after sulfur mustard exposure. J Res Med Sci. 2013;18(10):855.

29. Devadas S, Zaritskaya L, Rhee SG, Oberley L, Williams MS. Discrete generation of superoxide and hydrogen peroxide by $\mathrm{T}$ cell receptor stimulation. J Exp Med. 2002;195(1):59-70.

30. Caroleo M, Rispoli V, Arbitrio M, Strongoli C, Rainaldi G, Rotiroti D, et al. Chronic administration of paraquat produces immunosuppression of $\mathrm{T}$ lymphocytes and 
astrocytosis in rats. Toxic Subst Mech. 1996;15(3):183-94.

31. Annunziata M, Iorio M. The levels of glutathione and hemoglobin in sheep erythrocytes as a function of age. Ital J Anim Sci. 2004;3(3):283-6.

32. Witko-Sarsat V, Nguyen AT, Descamps-Latscha B. Immunomodulatory role of phagocyte- derived chloramines involving lymphocyte glutathione. Mediators Inflamm. 1993;2(3):235-41.

33. Victor, V. M., Rocha, M. and De la Fuente, M. Immune cells: free radicals and antioxidants in sepsis. Int Immunopharmacol. 2004;4(3):327-47.

34. Griffiths HR. ROS as signalling molecules in T cells--evidence for abnormal redox signalling in the autoimmune disease, rheumatoid arthritis. Redox Rep. 2005;10(6):273-80.

35. Mahmoudi M, Zamani Taghizadeh Rabe S, Balali-Mood M, Karimi G, Memar B, Rahnama M, et al. Immunotoxicity induced in mice by subacute exposure to berberine. J Immunotoxicol. 2016;13(2):255-62. 